\title{
Substantiation of the Way of Modernization of Shunting Diesel Locomotives
}

\author{
Serhii Buriakovskyi ${ }^{1}$, Artem Maslii $^{2}$ and Olga Pasko ${ }^{2 *}$ \\ ${ }^{1}$ Scientific Research and Design Institute Molniya, Ukraine \\ ${ }^{2}$ Ukrainian State University of Railway Transport, Ukraine
}

Submission: February 22, 2019; Published: March 13, 2019

*Corresponding author: Olga Pasko, Ukrainian State University of Railway Transport, Ukraine

\begin{abstract}
The analysis of the reconstruction process of traction means on the world railways shows that the railway polygon operated by diesel locomotive traction and the transport volume carried out by diesel locomotives on the railways occupy the leading place. Despite the fact that in the countries of Western Europe and the USA the process of introducing advanced types of traction has been completed or is almost completed, demand for diesel locomotives will remain stable worldwide. Moreover, these countries will require the replacement and modernization of outdated diesel locomotives. All this is driving the leading global diesel locomotive companies such as Brush Traction, Alstom, Toshiba, General Electric to work intensively on the creation of new diesel locomotive constructions. The global trend towards energy efficiency makes it necessary to move to more environmentally friendly and reliable shunting diesel locomotives. Given the fact that shunting diesel locomotives are often used as suburban railway locomotives in short, inactive sections, the issue of reducing fuel and energy consumption is currently an acute and priority task. They are also one of the most important elements of railway stations ensuring their uninterrupted operation, therefore the creation of hybrid units for shunting traction with advanced control systems is one of the actual scientific and technical tasks of the railway transport. The article addresses the problems of inefficient use of fuel and energy resources by shunting locomotives. The proposed functional scheme of the hybrid diesel locomotive makes it possible to introduce traction engine control systems to improve their properties.
\end{abstract}

Keywords: Shunting diesel locomotives; Hybrid diesel locomotives; Hybrid power transmission

\section{Introduction}

The efficient consumption of fuel and energy resources is one of the most important challenges facing the economies of developed countries. The railway transport sector is one of the largest power consumers in the national economy. Nowadays, energy efficiency is the most important factor in increasing the competitiveness of railways on the national and international market for transport services [1]. The major part of the fuel and energy resources of the railway transport is consumed for the traction of trains. Today it is $82 \%$ of total electrical energy consumption and $90 \%$ of diesel fuel consumption. In this connection the energy saving concentrates primarily on the main type of operation - the transportation process. From this point of view, the issue of increasing energy efficiency is very relevant for railways and requires further research. The practice shows that today more than $40 \%$ of all transportation operations on the railway are carried out by shunting diesel locomotives, therefore the modernization of such locomotives is the most expedient [2].

The main requirements for the new generation of shunting locomotives of this power are:
A. Maximum use of energy to achieve traction power, minimization of energy consumption for auxiliary needs and costs for the purchase of fuel and lubricants;

B. Minimizing labor costs throughout the lifecycle, including all types of maintenance and repair costs;

C. Environmental friendliness and high ergonomics that conform to current and prospective national and global standards.

In order to meet the above requirements, global locomotive manufacturers tend to introduce hybrid power transmissions in railway transport. However, most shunting diesel locomotives operated worldwide on the railways have a transmission without energy storage. According to statistics, more than $40 \%$ of shunting operations are locomotive downtime with the engine running and $10-15 \%$ of the time are movements without wagons [3]. The distribution of the operation modes of a shunting locomotive is shown in Figure 1. 


\section{Civil Engineering Research Journal}

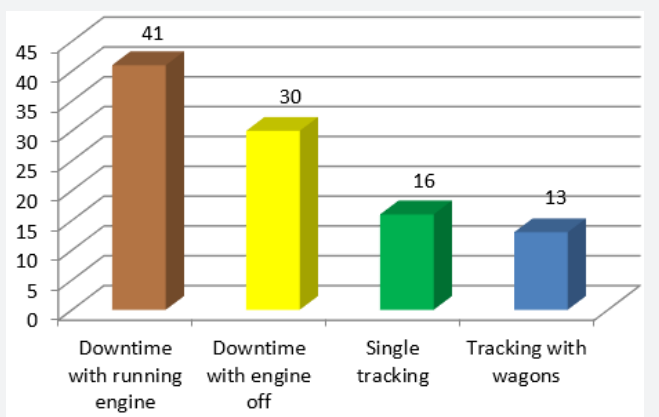

Figure 1: Distribution of the operation modes of a shunting locomotive.

Figure 1 above shows that the use of powerful shunting diesel locomotives is economically impractical, since the use of locomotives with partial loading leads to extra fuel consumption. Therefore, the transition to a hybrid system with a low-power diesel generator unit is the most promising trend today. Hybrid locomotives (or vehicles with an integrated power unit) hold an intermediate position between a conventional locomotive (with an internal combustion engine) and an electric locomotive (powered by overhead contact wires) [4]. The hybrid consists of two or more energy sources: a diesel generator of the unit, an accumulator, a buffer storage device, etc.

The analysis of alternatives to the new generation drive has shown that a competitive vehicle can actually be built using an integrated power plant. Such a plant consists of an internal combustion engine, a generator, an electric traction drive and an energy storage device, and advantageously combines the positive properties of each unit. Therefore, the priority today is an integrated plant with a thermal engine. With such a solution, fuel consumption is reduced by at least $40 \%$, since most of the shunting operation will be powered by a traction battery while ensuring high environmental friendliness of the locomotive [5].

Figure 2 shows a functional diagram of the hybrid diesel locomotive comprising a diesel engine, a synchronous starter

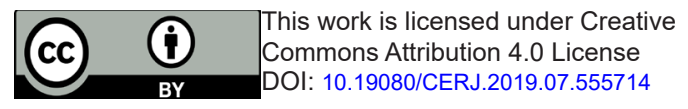

generator, a rectifier, an energy storage device (rechargeable battery, ionizers), a static converter and a traction engine, which can be either a DC or an AC engine.

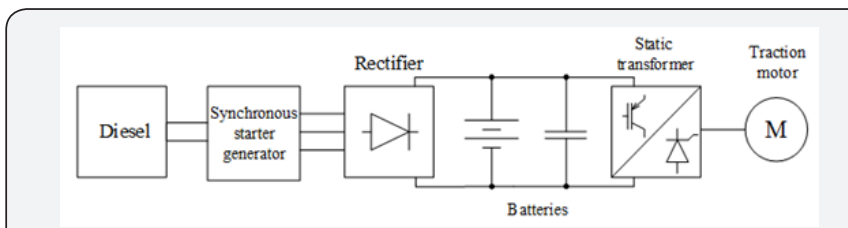

Figure 2: Functional diagram of the hybrid diesel locomotive.

\section{Conclusion}

The use of energy storage devices in the system eliminates the need for diesel engine speed control systems in favor of traction engine control systems. In the diesel locomotive shown above, the diesel engine is only started in driving modes with heavy trains and runs with rated rpm at rated fuel consumption.

\section{References}

1. Falendysh AP, Sumtsov AL, Klymenko OV (2013) Analysis of upgrade options locomotives series CHME3Technologies. Donetsk Institute of Railway Transport 36: 162-166.

2. Chernyak YuV, Hatchenko VO, (2014) Analysis of existing and future areas of application recuperative systems in transport to improve its energy efficiency. Technologies Donetsk Institute of Railway Transport 37: 134-139.

3. Varakyn AY, Varakyn YN, Menukhov VV (2007) Shunting and versatile locomotive with hybridterm propulsion and energy storage based on electrochemical capacitors. Science and Transport Equipment12: 3440.

4. Falendysh AP, Volodarets MV, Artemenko OV (2015) Determination of rational parameters of hybrid shunting locomotive at the chme3. Technologies. East Ukrainian National University of Dal 1(218): 253256.

5. Ovchynnykov VM (2010) Ways to reduce fuel consumption in shunting operations at railway stations. Bulletin of the Belarusian State University of Transport: Science and Transportation 2 (21): 151-158.

\footnotetext{
Your next submission with Juniper Publishers will reach you the below assets

- Quality Editorial service

- Swift Peer Review

- Reprints availability

- E-prints Service

- Manuscript Podcast for convenient understanding

- Global attainment for your research

- Manuscript accessibility in different formats

( Pdf, E-pub, Full Text, Audio)

- Unceasing customer service
}

Track the below URL for one-step submission https://juniperpublishers.com/online-submission.php 